\section{Postpartum breastfeeding status}

According to the abstract, ${ }^{1}$ it does not appear that the postpartum woman's lactation status was taken into account. So I am wondering, couldn't their status alter the findings, given some of the major hormonal, immune function, and metabolic differences between woman that exclusively breast feed vs formula feed?

\section{Christine Betzold}

Nursing, ProHealth Partners, Long Beach, CA, USA

Correspondence to Ms Christine Betzold, Prohealth Partners; Lacnackrnp@aol.com

Funding This letter received no specific grant from any funding agency in the public, commercial or not-for-profit sectors.

Competing interests None declared.

Patient consent Not required.

Provenance and peer review Not commissioned; internally peer reviewed. (c) Article author(s) (or their employer(s) unless otherwise stated in the text of the article) 2019. All rights reserved. No commercial use is permitted unless otherwise expressly granted.

\section{D) Check for updates}

To cite Betzold C. Ann Rheum Dis 2019;78:e37.

Received 14 March 2018

Accepted 16 March 2018

Published Online First 11 April 2018

\section{Linked}

http://dx.doi.org/10.1136/annrheumdis-2018-213427

Ann Rheum Dis 2019:78:e37. doi:10.1136/annrheumdis-2018-213414

\section{REFERENCE}

1 Eudy AM, Siega-Riz AM, Engel SM, et al. Effect of pregnancy on disease flares in patients with systemic lupus erythematosus. Ann Rheum Dis 2018:77:855-60. 